\title{
$R_{i}$
}

\author{
Journal of Public Value and Administration Insights \\ (JPVAI) \\ ISSN: 2663-9181 \\ www.readersinsight.net/jpvai
}

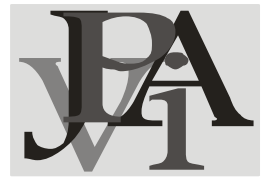

\section{Factors Affecting University Selection: Empirical Evidence from Hyderabad, Pakistan}

\author{
Ikramuddin Junejo ${ }^{* 1}$, Hafsah Amjad ${ }^{2}$, Rawah Memon ${ }^{3}$, Zohaib Pujwani ${ }^{4}$, Usman Rahar $^{5}$ \\ ${ }^{1,2,3,4,5}$ Management Sciences Department, SZABIST Hyderabad Campus
}

* Corresponding author: uddin.junejo@gmail.com

\begin{abstract}
The purpose of the study is to identify the impact of different factors affecting University Selection in Hyderabad, Pakistan. There are three independent variables selected, which are Financial Variable, Institutional Awareness and Institutional characteristics and the selected dependent variable is University selection. A 5 Likert scale adopted questionnaire was used as the instrument for the research. The data was gathered from a sample of 130 students and was analyzed by applying reliability (Cronbach's Alpha) and Multiple regression in SPSS version 20. It was concluded from the findings of the research that Financial Variable and Institutional characteristics have a positive and significant impact on university selection. Whereas, Institutional Awareness was found to have negative and insignificant impact on university selection. It is recommended that universities should consider these factors in order to increase the enrollment in their university. This will also improve the name and reputation of the university. Students should also consider these factors in order to select a proper university.
\end{abstract}

Keywords: Financial, Institutional Awareness, Institutional Characteristics

\section{ARTICLE INFORMATION}

Received: 21 Feburary 2019 Revised: 15 July 2019 Accepted: 28 July 2019

DOI: $10.31580 /$ jpvai.v2i2.894

\section{INTRODUCTION}

College selection plays a very important role in helping students in determining future career plans. All over the world the higher education system's governance has under gone multiple changes in recent years. Although these efforts have been taken, there is still requirement that the universities should increase the level of education that they are offering and improve the efficiency of education expenditures. In conclusion, the motivation for students in making their decision for university selection have gone through number of changes and the role of creating awareness for student enrollment has become highly significant (Ryan et.al 2014). In the selection of university, parental advice may vary from negligible to significance. Several researchers have summed up that usually parents are involved in guiding and providing financial support but student are the ones that make the final call regarding the choice of Institution. The choice process most likely involves interaction between students, parents, advisors, teachers, peers, relatives and personnel from institutions. (Ryan et.al 2014).

Institutional characteristics such as size, distance, quality of programs, availability of financial aid and cost (Ryan et.al 2014). In the effort to achieve a developed nation status, development of human resources is one of the strategies that the government has implemented (Lee, 2000). Education is one of the main instruments in developing human resources. Hence, education and skill development training are considered really important and are accorded high priority and it is hoped that through education, enough of well-educated, highly-skilled and strongly-motivated labor force can be developed.

As a result of the focus on education during last two decades, one can witness increase of new institutions of higher learning in India, especially in the private sector (Lee, 2000). This kind of development is a positive sign for the country as it facilitates choice of educational institutions for parents and students. Each year, there are many confused school leaving students who have myriad of options and have to make a choice for their further education and studies. Quite a number of students choose to go for further studies and some join the job market. For these students and their parents, they are faced with a rather critical choice. So far, there have been few studies on what criteria students resort to when selecting a proper university for their studies. (Chaubey et.al 2011).

\section{Empirical Literature Review}

\section{FINANCIAL VARIABLE}

Gyamfi et.al (2016), the impact of tuition fee on college selection in education industry in Kumasi, Ghana. Final year students will be the respondents. The sample size consisted of Three thirty-five (335) students. Multi stage sampling and questionnaires were the instruments for data collection. For the analysis the statistical data package is used for the social sciences (SPSS). To sum up, it was concluded that the fee is not the only factor but there are other factors as well that influence SHS graduates' university selection. The recommendation to the literature review is that other than tuition fees universities should also focus on other factors.

Geven (2012), this study is to examine the effect of increase in tuition fees on the students' choice of university. A semi-experimental research design was used by the researchers to determine the effect of the reforms, based on student university selection The data was carried from Higher education statistics agency. It results showed that enrolment declined by $15 \%$ in the treated groups because the tuition fee increased. The decline in enrolment was specifically pronounced for the respondents (students) in Older age group and from middle class, Service class. This study can help the universities in deciding proper ratio for increasing tuition fees and its maintenance so that it does not affect admissions.

Ciurej (2012), The Impact of providing scholarships and managing the structure of School and College enrollment. A quasi- 
experimental design based on pre- and post-intervention surveys of high school seniors was used, a significant WSA (Washington State Achiever) effect on educational outcomes was found, net of the demographic and socioeconomic composition of students across schools. Amongst the three intervention high schools, the program is more significant in only one school, significant after a lag in another school and not significant in a third. It is necessary to acknowledge concentrated efforts to change public schooling. Especially if tied to generous programs of providing financial aid, can make a significant impact in raising college enrollment.

Ackaert and Verhaeghe (2000), the effect of cost factors on involvement in college enrollment. We analyzed the impact of direct and indirect study costs on the university choice process. A questionnaire of 600 pupils was studied during 5th and 6th month of 1998. Again through a telephone first year students were questioned. It was concluded that the income of parents and the direct and indirect study costs of higher education still have a significant influence on student's university selection. Therefore, it is necessary to consider the tuition fee and other related costs before making an appropriate college choice.

H1: There is a significant impact of Financial Variable on University Selection in Hyderabad, Pakistan

\section{INSTITUTIONAL AWARENESS}

Ali et.al (2014), the study is about the impact of institutional awareness on students' choice of university. 572 surveys which were received from the students of 9th standard to sophomore of three different schools out of which one was from rural area and the other two were located in urban areas were analyzed. A positive relationship was found between institutional awareness and university selection after applying regression analysis. In addition, significant impact was observed on the social influences and family influences. Hence, having knowledge about institution prior to taking admissions should be taken into consideration.

Irfan et.al (2018), this study was conducted to find the impact of social media on admission of students in the Institutions that were area wise, both in rural and urban areas of Malaysia. Irfan et al., (2017) also established the relationship of social media and education tourism. The mining technique used called neural network is a very good classifier. It was found that handbill and television have significant impact; text messaging has temporary impact and websites and social media have no impact at all, in rural area. Whereas, in urban areas Social media, website and television have sustained, text messaging has a temporary impact, and handbills have no impact at all. This study will guide the institutions in adopting a new strategy whether an individual or combination of advertising can be used to effectively increase the popularity of institutions and increase the admissions.

Atarah and Peprah (2014), to find impact of advertisement on students' college enrolment decision. Questionnaires and interviews were used to collect data from the students and admission/marketing officers. SPSS was used to analyses data. Study resulted that advertising provides information to students that impacts on the college enrolment decision. Other factors which influenced the enrolment decision were family, friends, current students, etc. It is recommended that along with advertisements other awareness tools should also be practiced in order to increase awareness.

$\mathrm{H} 2$ : There is a significant impact of Institutional Awareness on University Selection in Hyderabad, Pakistan.

\section{INSTITUTIONAL CHARACTERISTICS}

Neil (2013), the study was carried out to find the impact of characteristics on private college enrolment decision in South Carolina. The sample size was taken from high school seniors. The sample included four participant institutions and 202 total participants. There was 5 point Likert scale on which specific factors were rated and instrument also had demographic questions. A factor analysis was conducted on the data and the results included family influence, institutional outreach, and campus/community characteristics. To find significant difference on above factors, an ANOVA was conducted from 4 participant institutions. The ANOVA resulted that institutional outreach and campus/community characteristics were significantly different among institutions and the family influence factor was not significantly different. This study can be used by enrollment managers to discover the factors that can influence freshmen at their institution so they can create programs accordingly.

Migin et.al (2015), the purpose of the study was to find out the impact of institutional characteristics on international students' choice of institutions of higher education in Malaysia. The sample size consisted of 265 respondents. This study found that institutional characteristics are significantly important for foreign students' choice of HEI in Malaysia. Academics and practitioners can use this study to focus on such characteristics that has an impact on foreign students to choose their respective private HEIs.

H3: There is a significant impact of Institutional characteristics on University Selection in Hyderabad, Pakistan.

\section{UNIVERSITY SELECTION}

Shahid et.al (2012), to identify factors that influences University selection. Data collection was by a qualitative approach through indepth interviews. The study resulted that word of mouth, environment, and social conditions are the main factors that influences the selection of university process. Also, it was also found that advertisement seems to be less important in selection process. This study can be used to increase college enrollment by considering the mentioned factors.

Jafari and Aliesmaili (2013), the research was conducted to investigate factors influencing the university choice among preuniversity students in the provinces of Gilan and Mazandaran in the north of Iran. The data was quantitative which was collected through a questionnaire with reliability 0.79 . Cluster method sampling was used. The study resulted that economic factors, university related factors, personal factors, and social factors influence student's university selection. It is recommended that universities should establish broader relationship with schools and students in order to give them the information they need for decision-making

Chaubey et.al (2011), factors that influence choice of institutions by higher educational institutions' students is explored in this study 541 students from different institutions was the sample size. The instruments for data collection were adapted questionnaire and an interview. The study resulted that the most influential factor for students' choice was vital information. The least significant factor which was found was sports activity. Ages of students and parent's income were not important in determining the choice of students. According to institution's area, it was declared that income of father is suitable for university selection.

\section{Methodology}

\section{DATA SOURCE}

The data source of the study is 'Primary', which involves the collection of research data directly from the respondents. In other words, the primary source is the direct data source related to the subject or problem. Here, data will be collected directly from the participants using a structured adopted questionnaire based on factors affecting university selection.

\section{Population of the Study}

The population of a research study is participants or the respondents of the study that possess similar characteristics or traits (Weiss, 2012). As the aim of the study is to explain the factors affecting the university selection in Hyderabad, Sindh province of 
Pakistan, therefore the population of the study consists of intermediate and 1 st year university students.

\section{SAMPLING STRATEGY}

In a primary research, sampling is an important component, which determines the number of respondents participating in the research study. Due to several constraints, including time, geographic and finance, it is important for a study to select a subset of the population. In this study author have applied convenience sampling technique in order to collect data for analysis that is kind of non-probability sampling.

\section{SAMPLE SIZE}

It is highly recommended that the at least 10 respondents should be considered for quanatiative and multiple regression analysis (Roscoe, 1975). In this study there 12 items or research questions for construct (variables), so $12 \times 20=120$ sample size. However, in order to get better results 130 respondent are considered in this research.

\section{RESEARCH INSTRUMENT}

Primary data source has been carried out in this research and data was collected through face-to-face from respondents with help of adopted questionnaire in five likert scale. This likert scale start with strongly disagree to strongly agree.

\begin{tabular}{|c|c|c|c|c|}
\hline Section & Variable & $\begin{array}{l}\text { No. of } \\
\text { items }\end{array}$ & $\begin{array}{l}\text { Five Point } \\
\text { Likert Scale }\end{array}$ & Source \\
\hline 1. & $\begin{array}{l}\text { University } \\
\text { Selection }\end{array}$ & 3 & Likert Scale & $\begin{array}{l}\text { Chatfield et } \\
\text { al. (2013) }\end{array}$ \\
\hline 2. & $\begin{array}{l}\text { Financial } \\
\text { Variable }\end{array}$ & 3 & Likert Scale & $\begin{array}{l}\text { Chatfield et } \\
\text { al. (2013) }\end{array}$ \\
\hline 3. & $\begin{array}{l}\text { Institutional } \\
\text { Awareness }\end{array}$ & 3 & Likert Scale & $\begin{array}{l}\text { Chatfield et } \\
\text { al. (2013) }\end{array}$ \\
\hline 4. & $\begin{array}{l}\text { Institutional } \\
\text { Characteristics }\end{array}$ & 3 & Likert Scale & $\begin{array}{l}\text { Chatfield et } \\
\text { al. (2013) }\end{array}$ \\
\hline
\end{tabular}

Results and Discussion

Reliability Test

\begin{tabular}{|c|c|c|c|}
\hline Constructs & $\begin{array}{l}\text { Vale of } \\
\text { Cronbach's } \\
\text { Alpha }\end{array}$ & $\begin{array}{l}\text { Items before } \\
\text { reliability } \\
\text { analysis }\end{array}$ & $\begin{array}{l}\text { Items after } \\
\text { reliability } \\
\text { analysis }\end{array}$ \\
\hline University Selection & .685 & 3 & 3 \\
\hline Financial Variable & .705 & 3 & 3 \\
\hline Institutional & .60 & 3 & 3 \\
\hline Awareness & & & \\
\hline $\begin{array}{l}\text { Institutional } \\
\text { characteristics }\end{array}$ & .753 & 3 & 3 \\
\hline
\end{tabular}

Table 2 reliability test the value of Cronbach's alpha is decided in order to conclude the adopted instrument reliability in this study. It can be noticed that our studied variables such as university selection (dependent), Financial, Institutional Awareness and Institutional characteristics Cronbach's alpha value revealed 68.5\%, 70.5\%, 60\% and $75.3 \%$ respectively. On basis of this result of reliability author of study can conclude that collected data is reliable and further analysis in SPSS can be applied with respect to hypothesis of this study.

\section{Multiple Regression Test}

Table 3 model summary result indicated that in this study independent variable explained to dependent variable university selection $70.5 \%$. Based on this result it is summarized that construct such as financial,
Institutional awareness and Institutional Characteristics are important in the context of university selection.

\begin{tabular}{l|l}
\multicolumn{2}{c}{ Table 3. Model Summary } \\
\hline Variables & $\mathbf{R}^{2}$ \\
\hline Financial variable (FV) & 0.705 \\
Institutional Awareness (IA) & \\
Institutional Characteristics (IC) & \\
\hline
\end{tabular}

a. Predictors: (Constant), FV, IA, IC

b. Dependent Variable: US

\section{ANOVA}

Table 4 shows the fitness of model with help of sig value, the value of $\mathrm{P}$ should be less the 0.05 . In this study ANOVA table reveal the $\mathrm{P}$ value 0.00 which indicated model of this study is fit because author had decided the confidence interval .95 or $95 \%$.

Table 4. ANOVA

\begin{tabular}{l|l} 
Model & Sig. \\
\hline Regression & $.000^{\mathrm{b}}$ \\
\hline & Source: Author' Estimations
\end{tabular}

\section{COFFICIENT}

A multiple regression analysis Table 5, shows two important values, the value of beta and p-value. The value of beta usually determines the relationship between dependent variable with independent variables whereas p-value shows the level of significance. In this study independent variables such as Financial $(\beta=0.280, p=.002)$ and Institutional Characteristics $(\beta=0.429, p=.000)$ are found positive and significant impact on dependent variable erecruitment. However, one independent variables such as Institutional Awareness $(\beta=-0.040, p=0.584)$ is found negative and insignificant impact on dependent variables university selection. We can see that in VIF column our all studied variables have values less than 10 that indicates in our research model has no multicollinearity. In this regard, our stated results are not overestimated.

Table 5. Coefficient

\begin{tabular}{l|l|l|l} 
Constructs & $\begin{array}{l}\text { Standardized } \\
\text { coefficient Beta }\end{array}$ & $\begin{array}{l}\text { Significant } \\
\text { value }\end{array}$ & $\begin{array}{l}\text { Collinearity } \\
\text { Statistics VIF }\end{array}$ \\
\hline Constant & & .000 & \\
FV & .280 & .002 & 1.630 \\
IA & -.040 & .584 & 1.074 \\
IC & .429 & .000 & 1.575 \\
\hline \multicolumn{4}{r}{ Source: Author' Estimations }
\end{tabular}

\section{Hypothesis Testing}

Table 6 that all revealed results in this study two of alternative hypothesis are accepted and one of alternative hypothesis is rejected.

Table 6. Hypothesis Testing

\begin{tabular}{|c|c|c|}
\hline $\begin{array}{l}\text { Independent } \\
\text { Variable }\end{array}$ & Hypothesis & Outcome \\
\hline $\begin{array}{l}\text { Financial } \\
\text { Variable }\end{array}$ & $\begin{array}{l}\text { There is a significant impact of } \\
\text { Financial Variable on University } \\
\text { Selection in Hyderabad, Pakistan. }\end{array}$ & Accepted \\
\hline $\begin{array}{l}\text { Institutional } \\
\text { Awareness }\end{array}$ & $\begin{array}{l}\text { There is a significant impact of } \\
\text { Institutional Awareness on University } \\
\text { Selection in Hyderabad, Pakistan. }\end{array}$ & Rejected \\
\hline $\begin{array}{l}\text { Institutional } \\
\text { characteristics }\end{array}$ & $\begin{array}{l}\text { There is a significant impact of } \\
\text { Institutional Characteristics on } \\
\text { University Selection in Hyderabad, } \\
\text { Pakistan. }\end{array}$ & Accepted \\
\hline
\end{tabular}




\section{Conclusion}

The main purpose of this research was to find the impact of various factors on university selection in Hyderabad, Sindh, Pakistan. In the previous studies, researchers explained various factors such as social environment, student background and educational achievement but this study is limited to institutional awareness, institutional characteristics and financial variable affecting university selection. For the conclusion of the study students of university and colleges were selected.

In this analysis, the impact of three independent variables; Financial Variable, Institutional Awareness and Institutional Characteristics on a dependent variable University Selection are considered. The findings of this study revealed that two of the three variables; Financial Variable and Institutional Characteristics studied above are found to have significant and positive impact on selection of university. Whereas the variable; Institutional Awareness is found to have insignificant and negative impact on University selection.

\section{Recommendations}

The universities should consider these factors in order to increase the enrollment in their university. This will also improve the name and reputation of the university. Students should also consider these factors in order to select a proper university.

This study can also further be extended to the selection criteria of schools and colleges. Other than just Universities, other services sector i.e. Insurance company, NGOs, hospitals can also be considered for future research on selection process. This study can also further be extended to other cities and provinces of Pakistan. Lastly, the respondents of the study can also be faculty members rather than the students.

\section{References:}

Atarah B. A. and Paprah A. A. (2014), "Assessing the Influence of Advertising on Student Enrolment in Private Tertiary Institutions in Ghana", International journal of business and social research, Vol 4, No.3, pp. $50-70$.

Ackaert, L. and Verhaeghe J. P. (2000), "The influence of financial factors on participation in higher education", European Conference on Educational Research, pp. 75-85.

Ali, R., Shah, N., and Baloch R. S. (2014), "The significance of awareness about selection and recruitment processes in students' career decision making", European Scientific Journal 10(14), pp. 857-7881.

Ashok, M.V., Apoorva, A., Suganthi, G. (2015), "Impact of Advertisements on Educational Institutions Admission using Classifier", International Journal of Computer Applications. Volume 118 - No.16, pp. 12-15.

Chaubey D. S., Subramaniam D. R. and Joshi S. (2011), "Factors Influencing Student's Choice for Higher Learning: An empirical study", Indira Management Review Volume-5 Issue -1, pp. 01-15.

Ciurej N. P., Herting., J. R. and Hirschman C. (2012), "The Impact of the Promise of Scholarships and Altering School Structure on College Plans, Preparation, and Enrollment. HHS", Public Access Author Manuscript Peer reviewed and accepted. Volume 4, issue 4, pp. 920935 .

Geven, K. (2012), "How Did the Latest Increase in Fees in England Affect Student Enrolment and Inequality", The European Higher Education Area, pp 479-500.

Gyamfi, E., Gyamfi I. and Qi, D. K. (2016), "The Influence of Tuition Fees on the Choice of University among Senior High School Graduates in Kumasi, Ghana", International Journal of Business and Management. Vol. 11, No. 12, pp. 222-229.

Irfan, A., Rasli, A., Sulaiman, Z., Sami, A., \& Qureshi, M. I. (2018). Use of Social Media Sites by Malaysian Universities and its Impact on University Ranking. International Journal of Engineering and Technology, 7(4.28), 67-71

Irfan, A., Rasli, A., Sami, A., \& Liaquat, H. (2017). Role of Social Media in Promoting Education Tourism. Advanced Science Letters, 23(9), 87288731.

Jafari P. and Aliesmaili A. (2013), "Factors Influencing the Selection of a University by High School Students", Journal of Basic and Applied Scientific Research, Volume 3(1), pp. 696-703.

Migin M. W., Falahat M., Yajid M. S. A. and Khatibi A. (2015), "Impacts of Institutional Characteristics on International Students' Choice of
Private Higher Education Institutions in Malaysia”, Canadian Center of Science and Education. Higher Education Studies; Vol. 5, No. pp. 3142.

Ryan Y. J., Rotich, T., Korrir, B., Muttai K., Kosgei M. and Koech J. (2014), "Factors influencing the Choice of College among Undergraduate students in Public Universities in Kenya", Australian Journal of Commerce Study SCIE Journal, pp. 70-75.

O'neil B. (2013), "College choice: factors influencing high school seniors' decision to enroll at private colleges in South Carolina", All Dissertations.

Shahid H., Shafique O. and Bodla O. H. (2012), "What factors affect a student choice of a university for higher education", Research on Humanities and Social Sciences, Vol 2, No.10, pp. 64-67. 